\title{
A monocenter retrospective study of serological, histological and genetic characteristics of celiac disease in Northern Central Italy
}

\author{
Stefania Lombardi ${ }^{1}$, Gloria Bertacca ${ }^{1}$, Isabella Giannelli ${ }^{1}$, Elena Bonomi ${ }^{1}$, Daniela Tornaboni ${ }^{2}$, \\ Marco Culli ${ }^{2}$, Andrea Cavazzana ${ }^{2}$, Antonella Puccini ${ }^{1}$, Paolo Franceschini ${ }^{1}$, Marco Friggeri ${ }^{1}$ \\ ${ }^{1}$ SSD Immunologia Allergologia e Patologia Molecolare, Azienda USL1 Massa e Carrara, Massa, Italy \\ ${ }^{2}$ UO Anatomia Patologia, Azienda USL1 Massa e Carrara, Carrara, Italy \\ Email: s.lombardi@usl1.toscana
}

Received 8 July 2013; revised 8 August 2013; accepted 15 August 2013

Copyright (C) 2013 Stefania Lombardi et al. This is an open access article distributed under the Creative Commons Attribution License, which permits unrestricted use, distribution, and reproduction in any medium, provided the original work is properly cited.

\begin{abstract}
Objective: To examine the seroprevalence, correlates and characteristics of Celiac disease (CD) in a population sample of a Northern Central Area of Italy, by a monocenter retrospective study. Methods: Between 2006 and 2010, serum samples of 9371 subjects (age range 6 months to 91 years) were screened for tissue transglutaminase IgA antibodies (IgA-tTG) by the Immunologia-Allergologia Unit of AUSL1 Massa-Carrara, an area with a population of approximately 150,000. Endomysial IgA antibodies (EMA), HLA typing and small-bowel biopsy were also performed when indicated. Results: Of the 9371 subjects, 269 (2.87\%) had positive antibody tests. The population was divided into several age groups and the highest prevalence (5.63\%) was found in the 6 months - 3 years group. The prevalence of IgA-tTG positivity was double in females compared to males. All IgA-tTG positive patients that were genotyped carried HLA-DQ2 or DQ8, none was $\alpha 5$ positive only. In positive IgA-tTG sera, levels of IgA-tTG were significantly higher in EMA positive than in EMA negative sera $(p<0.001)$ both in children and in adults. Ninety-five/269 IgA-tTG positive subjects underwent biopsy. IgA-tTG levels were different according to the histological degree of the lesion. When EMA were evaluated in IgA-tTG positive subjects the number of EMA negative sera was significantly higher in adults than in children. Conclusions: In summary, this study provides a monocenter retrospective analysis of serological, histological and genetic parameters of subjects with suspicion of CD in an area of Northern Central Italy from 2006 to 2010.
\end{abstract}

Keywords: Celiac Disease; Anti-Endomysium Antibodies; Anti-Transglutaminase Antibodies; Epidemiology; HLA-DR

\section{INTRODUCTION}

Celiac disease (CD) is an autoimmune enteropathy characterized by chronic intestinal inflammation resulting in villous atrophy and flattening of the small intestinal mucosa. CD develops in genetically predisposed individuals in response to the dietary ingestion of wheat gluten and similar proteins in barley and rye. Originally considered a rare malabsorption syndrome in childhood, CD is now recognized as a common disorder that may arise at any age, with growing proportion of new cases diagnosed in adults and patients with extraintestinal manifestations, such as esophageal reflux, osteoporosis, hypertransaminasemia and neurological symptoms [1,2]. Although CD is one of the most common lifelong diseases in western countries, most affected individuals remain undiagnosed [3]. This is apparently because many patients have atypical symptoms or none at all. The disease is characterized by the production of anti-tissue transglutaminase (IgA-tTG) and anti-endomysial IgA (EMA) antibodies [4-6]. Serological screening for the presence of these autoantibodies in individuals with characteristic symptoms of CD or with associated conditions is usually the initial step in detecting new cases. Although IgA-tTG and EMA appear to be good markers of the active phase of the disease, the definitive diagnosis requires a small-bowel biopsy showing the typical histological abnormalities (villous atrophy, crypt hyperplasia and intraepithelial lymphocytes) [7]. Population based studies have shown that the prevalences of CD in Europe and North America 
range from $0.7 \%$ to $2 \%$ [3,8-10]. The aim of this monocenter retrospective study was to investigate the serological, histological and genetic characteristics of subjects with CD suspicion who attempt to the Massa Hospital, Northern Central Italy, from 2006 up to 2010.

\section{METHODS}

\subsection{Study Population}

Subjects who underwent serological investigations by the Immunologia Allergologia Unit of Azienda USL1 Massa Carrara, between January 2006 and December 2010, because of suspicion of CD, were included in the present study. We examined 14247 subjects residing in the Massa Carrara area, an area with a population of approximately 150,000. Multiple accesses for the same subjects have been observed, therefore in the present study it has been decided to include data regarding only one access according to the following criteria: results of the last access were used for subjects with more accesses all negative for IgA-tTG; results of the first access positive for IgAtTG were used for subjects with more accesses one of which positive for IgA-tTG. On the basis of this recruitment criterion the data analysis was restricted to 9371 out of 14247 initial ones, of which 3234 male and 6137 female.

\subsection{Autoantibodies Measurements}

IgA-tTG were measured by EliA Celikey (Phadia, Friburg, Germany) using cutoffs as recommended by the manufacturer [11]. Results were expressed as arbitrary units (EliA U/ml) derived from standard curves of serial dilutions of calibrators.

Presence of EMA was measured by an immunofluorescence method using monkey esophagus as substrate (Euroimmun, Germany) [12]; a positive fluorescence at serum dilutions equal to or greater than 1:10 was considered positive. The EMA assay was performed when required by physician.

\subsection{Intestinal Histology}

Histological evaluations were performed blindly by a single skilled operator. The biopsy's grading was made according to the Marsh's classification modified by Oberhuber et al. [13].

\subsection{HLA Haplotypes and Nomenclature}

Genomic DNA was extracted from whole blood samples using Sample Prep Trombo (Diatech, Italy). The HLA typing was performed by a polymerase chain reaction (PCR) with a commercially available kit (Protrans HLA Celiac Disease Domino System, Protrans, Ketsch, Germany). The HLA kit contained multiplex PCRs for two
HLA-class II markers, the HLA-DQ2 (DQA1*0501 and DQB1*0201) and the HLA-DQ8 (DQA1*0301 and $\mathrm{DQB} 1 * 0302)$ and for beta globin protein as internal control. The obtained amplicons were resolved on $2 \%$ agarose gel and stained using ethidium bromide.

The term DQ2 belongs to the serologic HLA nomenclature, and it specifies an epitope on the $\beta 2$ chain. However with time, in $\mathrm{CD}$, the term has usually referred to a particular $\alpha 5 \beta 2$ DQ2 dimer encoded by DQA $1 * 05$ and DQB1*02 alleles. Therefore, DQ2 is used to indicate subjects carrying both the alleles, whereas individuals DQA $1 * 05$ negative/DQB $1 * 02$ positive, in which the $\beta 2$ chain forms dimer with a different $\alpha$ chain, are simply named $\beta 2$. A single or double dose of $\mathrm{DQB} 1 * 02$ is indicated as $\mathrm{B} 1 * 02 / \mathrm{X}$ or $\mathrm{B} 1 * 02 / 02$, respectively. The phenotype coded by DQA $1 * 05$ allele in absence of DQB $1 * 02$ is designed $\alpha 5$.

\subsection{Statistical Analysis}

Discrete variables were compared, by group, using chi square test. When comparing the serological assays by age groups, the Mann-Whitney nonparametric U test was used and results were presented as median concentrations. Values of $\mathrm{p}<0.05$ were considered to be significant.

\section{RESULTS}

The general demographic characteristics of the screened subjects in the years, the age distribution and the number of new IgA-tTG identified patients are summarized in Table 1.

Of the 9371 screened subjects, 269 (2.87\%) were IgAtTG positive. When the population was subdivided into age groups, the highest prevalence (5.63\%) was found in the 6 months - 3 years group. Moreover, subdividing the population into children (6 months - 15 years) and adults (>15 years) it was observed that 98 out of 2625 (3.73\%) children and 171 out of 6746 (2.53\%) adults were IgAtTG positive, respectively. This significant difference ( $p$ $<0.001$ ) indicates that the IgA-tTG seropositivity is found mostly in pediatric age.

The gender distribution of the studied population is reported in Table 2 . The pediatric population is equally divided into female and male subjects; on the contrary, in the adult group, female subjects are more than double compared to male subjects. The IgA-tTG prevalence was therefore calculated considering the pediatric population: 66 out of 1317 (5.01\%) female subjects and 32 out 1308 (2.44\%) males were IgA-tTG positive respectively, with a ratio female/male $=2 / 1$.

Of the 9371 subjects, 476 were genotyped for HLADRB1, DQA1 and DQB1 loci. As it has not always been possible to have certain information regarding the clinical reason of the genotype request i.e. first degree of re- 
Table 1. IgA-tTG positivity.

\begin{tabular}{|c|c|c|c|}
\hline \multirow[t]{2}{*}{ Year } & \multirow{2}{*}{$\begin{array}{l}\mathrm{N}^{\circ} \text { of screened } \\
\text { subjects }\end{array}$} & \multicolumn{2}{|c|}{$\begin{array}{l}\text { Incidence of IgA-tTG } \\
\text { positive subjects }\end{array}$} \\
\hline & & $\mathrm{N}^{\circ}$ & $\%$ \\
\hline 2006 & 2290 & 68 & 2.96 \\
\hline 2007 & 2009 & 45 & 2.23 \\
\hline 2008 & 1477 & 42 & 2.84 \\
\hline 2009 & 1840 & 60 & 3.26 \\
\hline \multirow[t]{2}{*}{2010} & 1755 & 54 & 3.07 \\
\hline & & \multicolumn{2}{|c|}{$\begin{array}{l}\text { Prevalence of IgA-tTG } \\
\text { positive subjects }\end{array}$} \\
\hline Age group & $\begin{array}{l}\mathrm{N}^{\circ} \text { of screened } \\
\text { subjects }\end{array}$ & $\mathrm{N}^{\circ}$ & $\%$ \\
\hline $6-36$ months & 834 & 47 & 5.63 \\
\hline $4-10$ years & 1094 & 32 & 2.92 \\
\hline 11 - 15 years & 697 & 19 & 2.72 \\
\hline 16 - 30 years & 1681 & 56 & 3.33 \\
\hline 31 - 45 years & 2227 & 71 & 3.18 \\
\hline 46 - 60 years & 1473 & 28 & 1.90 \\
\hline 61 - 80 years & 1174 & 14 & 1.19 \\
\hline$>80$ years & 191 & 2 & 1.04 \\
\hline
\end{tabular}

Table 2. IgA-tTG prevalence per gender.

\begin{tabular}{ccccc}
\hline & & & \multicolumn{2}{c}{$\begin{array}{c}\text { IgA-tTG positive } \\
\text { subjects }\end{array}$} \\
\cline { 2 - 5 } & Gender & $\mathrm{N}^{\circ}$ subjects & $\mathrm{N}^{\circ}$ & $\%$ \\
\hline \multirow{2}{*}{$\begin{array}{c}\text { c months }^{*} \\
15 \text { years }\end{array}$} & Female & 1317 & 66 & 5.01 \\
& Male & 1308 & 32 & 2.44 \\
& Total & 2625 & 98 & 3.73 \\
$>15$ years & Female & 4820 & 121 & 2.51 \\
& Male & 1926 & 50 & 2.59 \\
& Total & 6746 & 171 & 2.53 \\
\hline
\end{tabular}

lationship, or clinical picture suggestive of $C D$, we evaluated only the haplotype frequency of the studied population (Table 3).

Of all subjects positive for HLA CD predisposing alleles, 57\% carried DQ2 and/or DQ8 heterodimers, 16\% had $\beta 2$ chain and $27 \%$ was $\alpha 5$ positive. All IgA-tTG patients that were genotyped carried HLA-DQ2 or DQ8, none was $\alpha 5$ positive only.

Out of 9371 subjects, 269 were positive for IgA-tTG and levels of IgA-tTG were significantly higher in children than in adults (median value $89 \mathrm{U} / \mathrm{ml}$ and $38 \mathrm{U} / \mathrm{ml}$ respectively, $\mathrm{p}<0.001$, data not reported). Results of IgA-tTG sera screened for EMA are reported in Table 4; levels of IgA-tTG were significantly higher in EMA positive than in EMA negative sera $(\mathrm{p}<0.001)$ both in children and in adults.

Ninety-five subjects out of 269 IgA-tTG positive sub-
Table 3. HLA haplotypes.

\begin{tabular}{lcc}
\hline & $\begin{array}{c}\text { General } \\
\text { population }\end{array}$ & $\begin{array}{c}\text { IgA-tTG and } \\
\text { EMA positive } \\
\text { subjects }\end{array}$ \\
\hline DR3-DQ2/- & 120 & 7 \\
DR3-DQ2/DR7-DQ2 & 30 & 3 \\
DR3-DQ2/DR5-DQ7 & 2 & 0 \\
DR5-DQ7/DR7-DQ2 & 35 & 3 \\
DR3-DQ2/DR3-DQ2 & 1 & 3 \\
DR4-DQ8 & 45 & 2 \\
DQA1*05 & 111 & 0 \\
DQB1*02/02 and DQB1*02/X & 64 & 5 \\
HLA other than DQ2/DQ8 & 68 & 0 \\
\hline
\end{tabular}

Table 4. IgA-tTG levels in EMA screened sera.

\begin{tabular}{ccccc}
\hline & \multicolumn{2}{c}{ EMA positive } & \multicolumn{2}{c}{ EMA negative } \\
\cline { 2 - 5 } & $\begin{array}{c}\mathrm{N}^{\circ} \\
\text { subjects }\end{array}$ & $\begin{array}{c}\text { IgA-tTG } \\
\text { median }(\mathrm{U} / \mathrm{ml})\end{array}$ & $\begin{array}{c}\mathrm{N}^{\circ} \\
\text { subjects }\end{array}$ & $\begin{array}{c}\text { IgA-tTG } \\
\text { median }(\mathrm{U} / \mathrm{ml})\end{array}$ \\
\hline $\begin{array}{c}6 \text { months }- \\
15 \text { years }\end{array}$ & 59 & 99 & 23 & 21 \\
$>15$ years & 60 & 61 & 57 & 28 \\
\hline
\end{tabular}

jects accepted to undergo biopsy.

Levels of IgA-tTG varied according to the histological degree of the lesion, as reported in Table 5.

IgA-tTG levels correlate well with the severity of the lesion as already reported [14,15].

As reported in Methods, EMA was performed only when expressly required, therefore 199 out of 269 IgAtTG positive sera were investigated for EMA (Table 6).

It was found that the number of EMA negative sera was significantly higher in adults than in children both in the studied population and in the 77 samples in which biopsy was performed.

\section{DISCUSSION}

The prevalence of $\mathrm{CD}$ in the studied population of this area of Northern Central Italy is $2.87 \%$. This result is not in contrast with that of $0.7 \%-2 \%$ reported in previous studies on general population [3,8-10] as we investigated a population of $C D$ suspected subjects. We estimated the prevalence of CD assuming that all IgA-tTG positive subjects had $\mathrm{CD}$. The lack of confirmation of the diagnosis by means of an intestinal biopsy in all IgA-tTG positive subjects may represent a potential limitation of the study.

However, this assumption is supported by previous studies [16-18] and by our observation that the $87 \%$ of IgA-tTG positive subjects who underwent intestinal biopsy had a lesion consistent with CD; the remaining 13\% of subjects had type I-II lesions in the presence of gas- 
Table 5. IgA-tTG level in biopsied subjects.

\begin{tabular}{ccc}
\hline \multirow{2}{*}{$\begin{array}{c}\text { Mucosal histopathology } \\
\text { Marsh Oberhuber classification }\end{array}$} & \multicolumn{2}{c}{ IgA-tTG level } \\
\cline { 2 - 3 } & $\mathrm{N}^{\circ}$ subjects & Median (U/ml) \\
\hline Type 0 & 0 & \\
Type I & 6 & 18 \\
Type II & 6 & \\
Type IIIa & 19 & 54 \\
Type IIIb & 23 & 67 \\
Type IIIc & 41 & 128 \\
\hline
\end{tabular}

Table 6. EMA in positive IgA-tTG subjects.

\begin{tabular}{|c|c|c|c|c|}
\hline & \multicolumn{4}{|c|}{ All subjects } \\
\hline & \multicolumn{2}{|c|}{ Adults } & \multicolumn{2}{|c|}{ Children } \\
\hline & $\begin{array}{c}\text { EMA } \\
\text { negative }\end{array}$ & $\begin{array}{c}\text { EMA } \\
\text { positive }\end{array}$ & $\begin{array}{c}\text { EMA } \\
\text { negative }\end{array}$ & $\begin{array}{c}\text { EMA } \\
\text { positive }\end{array}$ \\
\hline \multirow{4}{*}{$\begin{array}{c}\text { Mucosal } \\
\text { histopathology } \\
\text { Marsh Oberhuber } \\
\text { classification }\end{array}$} & 32 & 85 & 7 & 75 \\
\hline & \multicolumn{4}{|c|}{ Biopsied subject } \\
\hline & \multicolumn{2}{|c|}{ Adults } & \multicolumn{2}{|c|}{ Children } \\
\hline & $\begin{array}{c}\text { EMA } \\
\text { negative }\end{array}$ & $\begin{array}{c}\text { EMA } \\
\text { positive }\end{array}$ & $\begin{array}{c}\text { EMA } \\
\text { negative }\end{array}$ & $\begin{array}{c}\text { EMA } \\
\text { positive }\end{array}$ \\
\hline Type 1 & 3 & 6 & & 1 \\
\hline Type 2 & 1 & 1 & & 1 \\
\hline Type IIIa & 2 & 8 & & \\
\hline Type IIIb & 2 & 15 & 1 & 1 \\
\hline Type IIIc & 4 & 19 & 1 & 11 \\
\hline
\end{tabular}

trointestinal symptoms and HLA haplotypes compatible with $\mathrm{CD}$. The prevalence of $\mathrm{CD}$ is almost constant during the time-span examined, being $2.96 \%$ in 2006 and $3.07 \%$ in 2010.

In this study, a bimodal pattern of $\mathrm{CD}$ diagnosis was observed with a first peak at 6 to 36 months and a second one at 16 to 45 years.

The total prevalence of CD decreases in a statistically significant manner in the pediatric population from the highest value of $5.63 \%$ to $2.72 \%$ of the 6 - 36 months and 11 - 15 years respectively, and the decreasing trend could also be seen in the adult population with the highest value of $3.33 \%$ and the lowest one of $1.04 \%$ in the 16 - 30 and $>80$ age groups respectively.

Overall, the prevalence of $C D$ is twice as frequent among females as compared to males, possibly because the necessary HLA haplotypes, DQ2/DQ8, are more frequent in female than in male patients [19]. Inside the adult population the request of IgA-tTG is much more frequent for females especially during the third to fourth decades of their life; this could be explained either because females tend to seek medical care more often than males [10] or because pregnancy or other hormonal disorders could trigger CD symptoms [20]. Several studies indicate that CD can develop also in the elderly [21-23] with variable symptoms ranging from silent disease, to vague abdominal complaints, to anemia. These limited symptoms could also lead to a delay in diagnosis. In the studied population, $15 \%$ of $\mathrm{CD}$ diagnostic requests involved subjects over 60 years of age, thus indicating that in our study area the level of attention to this disease by the physicians is very high throughout the patient's life.

According to our HLA genotype results, in the studied population the mostly represented genotypes related to CD are DQ2 and $\beta 2$ (62\%) with DQ8 at $11 \%$; inside IgA-tTG patients DQ2 and $\beta 2$ genotypes arise to $91 \%$ while DQ8 doesn't change significantly (9\%) and none was $\alpha 5$ positive only or HLA different from DQ2/DQ8, thus confirming what reported in previous studied [24].

Serological analysis for IgA-tTG shows in the 269 positive subjects that the level of antibodies was significantly higher in the pediatric population than in adults and it shows to correlate well with severity of biopsy as already reported [25]. Moreover when IgA-tTG positive sera were tested for EMA it has been found that level of IgA-tTG significantly correlates with presence of EMA either in children than in adults.

The prevalence figure (18\%) for EMA negative CD in the biopsied population was slightly higher when compared with that of $15 \%$ reported in other studies [26,27].

Almost all EMA negative patients were adults (12 versus 2). Further studies would be required to explain this finding, however during a longstanding immune reaction, antibodies with increasing avidity are produced which makes it understandable why older patients with CD may have lower IgA-tTG and EMA serum levels than the younger ones; thus longstanding $\mathrm{CD}$ might even result in seronegativity.

In summary, this paper provides for the first time a picture of CD in an area of Northern Central Italy, one of the countries with the highest incidence of $\mathrm{CD}$ in the world [28].

\section{ACKNOWLEDGEMENTS}

We thank Dr. Alessandro Celi for critical review of the manuscript.

\section{REFERENCES}

[1] Fasano, A., Araya, M., Bhatnagar, S., Cameron, D., Catassi, C., Dirks, M., Mearin, M.L., Ortigosa, L. and Phillips, A. (2008) Celiac disease working group. FISPGHAN: Federation of International Societies of Pediatric Gastroenterology, Hepatology, and Nutrition consensus report on celiac disease. Journal of Pediatric Gastroenterology and Nutrition, 47, 214-219. doi:10.1097/MPG.0b013e318181afed

[2] Mearin, M.L. (2007) Celiac disease among children and adolescents. Current Problems in Pediatrics and Adlescent Health Care, 37, 86-105. 
doi:10.1016/j.cppeds.2007.01.001

[3] Catassi, C., Kryszak, D., Louis-Jacques, O., Duerksen, D.R., Hill, I., Crowe, S.E., Brown, A.R., Procaccini, N.J., Wonderly, B.A., Hartley, P., Moreci, J., Bennett, N., Horvath, K., Burk, M. and Fasano, A. (2007). Detection of Celiac disease in primary care: A multicenter case-finding study in North America. America Journal of Gastroenterology, 102, 1454-1460. doi:10.1111/j.1572-0241.2007.01173.X

[4] Abdulkarim, A.S. and Murray, J.A. (2003) The diagnosis of celiac disease. Alimentary Pharmacology Therapeutics, 17, 987-999. doi:10.1046/j.1365-2036.2003.01442.x

[5] Chan, A.W., Butzner, J.D., McKenna, R. and Fritzler, M.J. (2001) Tissue transglutaminase enzyme-linked immunosorbent assay as a screening test for celiac disease in pediatric patients. Pediatrics, 107, E8. doi:10.1542/peds.107.1.e8

[6] Bürgin-Wolff, A., Dahlbom, I., Hadziselimovic, F. and Petersson, C.J. (2002) Antibodies against human tissue transglutaminase and endomysium in diagnosing and monitoring coeliac disease. Scandinavian Journal of Gastroenterology, 37, 685-691. doi:10.1080/00365520212496

[7] Walker-Smith, J.A., Guandalini, S., Schmitz, J., Shmerling, D.H. and Visakorpi, J.K. (1990) Revised criteria for diagnosis of celiac disease. Archives of Disease in Childhood, 65, 909-911.

[8] Mäki, M., Mustalahti, K., Kokkonen, J., Kulmala, P., Haapalahti, M., Karttunen, T., Ilonen, J., Laurila, K., Dahlbom, I., Hansson, T., Höpfl, P. and Knip, M. (2003) Prevalence of Celiac disease among children in Finland. New England Journal of Medicine, 348, 2517-2524. doi:10.1056/NEJMoa021687

[9] West, J., Logan, R.F., Hill, P.G., Lloyd, A., Lewis, S., Hubbard, R., Reader, R., Holmes, G.K. and Khaw, K.T. (2003) Seroprevalence, correlates, and characteristics of undetected coeliac disease in England. Gut, 52, 960-965. doi:10.1136/gut.52.7.960

[10] Freeman, H.J., Chopra, A., Clandinin, M.T. and Thomson A.B. (2011) Recent advances in celiac disease. World Journal of Gastroenterology, 1, 2259-2272. doi:10.3748/wjg.v17.i18.2259

[11] Ress, K., Harro, M., Maaroos, H.I., Harro, J., Uibo, R. and Uibo, O. (2007) High prevalence of coeliac disease: Need for increasing awareness among physicians. Digestive and Liver Disease, 39, 136-139. doi:10.1016/j.dld.2006.07.012

[12] Not, T., Horvath, K., Hill, I.D., Partanen, J., Hammed, A., Magazzu, G. and Fasano, A. (1998) Celiac disease risk in the USA: High prevalence of antiendomysium antibodies in healthy blood donors. Scandinavian Journal of Gastroenterology, 33, 494-498. doi:10.1080/00365529850172052

[13] Oberhuber, G., Granditsch, G. and Vogelsang, H. (1999) The histopathology of coeliac disease: Time for a standardized report scheme for pathologists. European Journal of Gastroenterology and Hepatology, 11, 1185-1194. doi:10.1097/00042737-199910000-00019

[14] Donaldson, M.R., Firth, S.D., Wimpee, H., Leiferman, K.M., Zone, J.J., Horsley, W., O’Gorman, M.A., Jackson,
W.D., Neuhausen, S.L., Hull, C.M. and Book, L.S. (2007) Correlation of duodenal histology with tissue transglutaminase and endomysial antibody levels in pediatric celiac disease. Clinical Gastroenterology and Hepatology, 5, 567-573. doi:10.1016/j.cgh.2007.01.003

[15] Van Meensel, B., Hiele, M., Hoffman, I., Vermeire, S., Rutgeerts, P., Geboes, K. and Bossuyt, X. (2004) Diagnostic accuracy of ten second-generation (human) tissue transglutaminase antibody assays in celiac disease. Clinical Chemistry, 50, 2125-2135. doi:10.1373/clinchem.2004.035832

[16] Chin, M.W., Mallon, D.F., Cullen, D.J., Olynyk, J.K., Mollison, L.C. and Pearce, C.B. (2004) Screening for coeliac disease using anti-tissue transglutaminase antibody assays, and prevalence of the disease in an Australian community. Medical Journal of Australia, 190, 429-432.

[17] Lohi, S., Mustalahti, K., Kaukinen, K., Laurila, K., Collin, P., Rissanen, H., Lohi, O., Bravi, E., Gasparin, M., Reunanen, A. and Mäki, M. (2007) Increasing prevalence of coeliac disease over time. Aliment Pharmacology and Therapeutics Aims, 26, 1217-1225. doi:10.1111/j.1365-2036.2007.03502.x

[18] Volta, U. and Villanacci, V. (2011) Celiac disease: Diagnostic criteria in progress. Cellular \& Molecular Immunology, 8, 96-102. doi:10.1038/cmi.2010.64

[19] Megiorni, F., Mora, B., Bonamico, M., Barbato, M., Montuori, M., Viola, F., Trabace, S. and Mazzilli, M.C. (2008) HLA-DQ and susceptibility to celiac disease: Evidence for gender differences and parent-of-origin effects. American Journal of Gastroenterology, 103, 997-1003. doi:10.1111/j.1572-0241.2007.01716.x

[20] Fasano, A., Berti, I., Gerarduzzi, T., Not, T., Colletti, R.B., Drago, S., Elitsur, Y., Green, P.H.R., Guandalini, S., Hill, I., Pietzak, M., Ventura, A., Thorpe, M., Kryszak, D., Fornaroli, F., Wasserman, S.S., Murray, J.A. and Horvath, K. (2003) A multicenter study on the sero-prevalence of celiac disease in the United States among both at risk and not at risk groups. Archives of Internal Medicine, 163, 286-292. doi:10.1001/archinte.163.3.286

[21] Vilppula, A., Kaukinen, K., Luostarinen, L., Krekelä, I., Patrikainen, H., Valve, R., Mäki, M. and Collin, P. (2009) Increasing prevalence and high incidence of celiac disease in elderly people: A population-based study. $B M C$ Gastroenterology, 9, 49-53. doi:10.1186/1471-230X-9-49

[22] Freeman, H.J. (2008) Adult celiac disease in the elderly. World Journal Gastroenterology, 14, 6911-6914. doi:10.3748/wig.14.6911

[23] Thomson, A.B. (2009) Small intestinal disorders in the elderly. Best Practice \& Research Clinical Gastroeterology, 23, 861-874. doi:10.1016/j.bpg.2009.10.009

[24] Megiorni, F., Mora, B., Bonamico, M., et al. (2009) HLADQ risk gradient for celiac disease. Human Immnology, 70, 55-59. doi:10.1016/j.humimm.2008.10.018

[25] Abrams, J.A., Brar, P., Diamond, B., Rotterdamn H. and Green, P.H. (2006) Utility in clinical practice of immunoglobulin a anti-tissue transglutaminase antibody for the diagnosis of celiac disease. Clinical Gastroeterology Hepatology, 4, 726-730. doi:10.1016/j.cgh.2006.02.010

[26] Salmi, T.T., Collin, P., Korponay-Szabó, I.R., Laurila, K., 
Partanen, J., Huhtala, H., Király, R., Lorand, L., Reunala, T., Mäki, M., Kaukinen,K. (2006) Endomysial antibodynegative coeliac disease: Clinical characteristics and intestinal autoantibody deposits. Gut, 55, 1746-1753. doi:10.1136/gut.2005.071514

[27] Collin, P., Kaukinen, K., Vogelsang, H., Korponay-Szabó, I., Sommer, R., Schreier, E., Volta, U., Granito, A., Veronesi, L., Mascart, F., Ocmant, A., Ivarsson, A., Lagerqvist, C., Bürgin-Wolff, A., Hadziselimovic, F, Furlano, R.I., Sidler, M.A., Mulder, C.J., Goerres, M.S., Mearin, M.L., Ninaber, M.K., Gudmand-Høyer, E., Fabiani, E.,
Catassi, C., Tidlund, H., Alainentalo, L. and Mäki, M. (2005) Antiendomysial and antihuman recombinant tissue transglutaminase antibodies in the diagnosis of coeliac disease: A biopsy-proven European multicentre study. European Journal Gastroenterology and Hepatology, 17, 85-91. doi:10.1097/00042737-200501000-00017

[28] D’Archivio, M., Silano, M., Fagnani, C., Scazzocchio, B., Nisticò, L., Giovannini, C., Varì, R., D’Ippolito, C., Cotichini, R., Stazi, M.A. and De Vincenzi, M. (2004) Clinical evolution of celiac disease in Italy 1982-2002. Journal of Clinical Gastroenterology, 38, 877-879. 